University of Wollongong

Research Online

Faculty of Law - Papers (Archive)

Faculty of Business and Law

$1-6-2005$

\title{
Environmental Justice in Australia: When the RATS became IRATE
}

E. Arcioni

University of Wollongong, arcioni@uow.edu.au

Glenn Mitchell

University of Wollongong, gmitchel@uow.edu.au

Follow this and additional works at: https://ro.uow.edu.au/lawpapers

Part of the Law Commons

\section{Recommended Citation}

Arcioni, E. and Mitchell, Glenn: Environmental Justice in Australia: When the RATS became IRATE 2005. https://ro.uow.edu.au/lawpapers/20

Research Online is the open access institutional repository for the University of Wollongong. For further information contact the UOW Library: research-pubs@uow.edu.au 


\title{
Environmental Justice in Australia: When the RATS became IRATE
}

\begin{abstract}
Environmental justice is a concept used in the United States to describe and analyse environmental politics. That concept also has application outside the country of its origin. In Australia the case study of a dispute between residents, industry and government in the town of Port Kembla provides an example of how environmental justice can be given specific meaning in a local context. Observations of the 'politics' of an environmental dispute are made.

Disciplines

Law

Publication Details

This article was originally published as Arcioni, E and Mitchell, G, Environmental Justice in Australia: When the RATS became IRATE, Environmental Politics, 14(3), June 2005, 363-379. Copyright Taylor \& Francis. Original journal available here.
\end{abstract}




\title{
Environmental Justice in Australia: When the RATS Became IRATE Elisa Arcioni* \& Glenn Mitchell** \\ *Faculty of Law, University of Wollongong, NSW Australia 2522 \\ ${ }^{\star \star}$ Faculty of Arts, University of Wollongong, NSW Australia 2522
}

\begin{abstract}
Environmental justice is a concept used in the United States to describe and analyse environmental politics. That concept also has application outside the country of its origin. In Australia the case study of a dispute between residents, industry and government in the town of Port Kembla provides an example of how environmental justice can be given specific meaning in a local context. Observations of the 'politics' of an environmental dispute are made.
\end{abstract}

\section{Introduction}

On 29 May 1997, the New South Wales Land and Environment Court began hearing a case brought by Helen Hamilton,[1] a long-time resident of Port Kembla, New South Wales (NSW), Australia. She had successfully mounted a court challenge to the state government's approval of an application by a Japanese consortium to reopen a copper smelter at Port Kembla. However, the legal challenge failed to proceed and Hamilton lost her opportunity to provoke legal scrutiny of the government's decision. Just hours before Hamilton's case was due to commence, the NSW government introduced legislation that would guarantee the smelter's reopening and make any court action redundant. Put simply, rather than getting her day in court, Hamilton got a matter of hours. What was this case about? What led to this extraordinary situation of an individual attempting to question a state government decision in court and then having that chance quashed before the formalities began? What relevance might this case have for environmental justice in Australia?

Environmental justice is a term replete with political and moral implications. The concept emerged in the USA in the 1970s and has developed as an area of policy and academic research. [2] However, environmental justice, as understood in the USA, has had limited impact or application in other parts of the world. This article considers the notion of environmental justice as it applies to the Australian contexts of environmental regulation, politics and policy. A specific element of environmental justice applicable to the Australian context is identified - public participation. This is explored through the lens of a particular industrial site $-a$ copper smelter - and the related public involvement and disquiet caused by the pollution emanating from this smelter. 
This study examines the way in which Port Kembla residents engaged in community action as a form of public participation. It considers the implications for environmental justice of the way in which a resident's attempted legal challenge was defeated by legislation. The article has four parts. In the first part, it addresses the concept of environmental justice as it has developed in the USA and its possible utility in an Australian context through the concept of public participation. The second part puts the case study into a geographic and historical context. The third part sets out the case study. The final part draws out the ways in which public participation was manifest in the case study. The essay ends with analysis of the effect of the government's action on environmental justice.

\section{Environmental Justice and Public Participation}

Environmental justice is a movement that began in the USA in the 1970s, with the activities of local community groups. It has grown into an area of interest for activists, government agencies and academics. As Kyte argues (1994: 279), it is one of the few environmental movements to have 'come so far so fast'. Communities involved in the initial stages of the environmental justice movement were predominantly made up of minority groups, generally comprising persons from low socio-economic backgrounds. Women played a major role. The groups were established to combat specific sources of pollution or toxic wastes in their local area, which were directly affecting their health (Melosi 1995: 3). Those involved generally lacked experience in the mainstream environmental movement, although they frequently had a history in civil rights political struggles (Brown 1995: 15). The tactics used by the groups included protests, demonstrations, lobbying and fact-finding hearings.

The focus of the groups was always a specific urban problem, with the survival of the human residents at the centre of their work. This meant that to gain support from the mainstream environmental movements would require a redefinition of 'the environment' to include not only glamorous photogenic animal species or spectacular pristine wilderness but also urban situations and human health risks, such as risks to human health from industrial pollution (Harvey 1996). Further, the groups' human focus fuelled a growing debate about the human-nature relationship and, more generally, between 'ecocentric' and 'anthropocentric' positions (Melosi 1995: 11).

By the 1980s, the environmental justice movement had developed into a general area of research and interest (Kyte 1994: 258). It came to be defined by reference to the necessary integration of environmental concerns and social justice, including issues dealing with health and race. It specifically alluded to the discriminatory nature of siting industries and toxic waste repositories in places which affected minority groups. It also led to the examination of power politics and the nature of capitalism, including the consequences of industrial production 
(Bullard 1993: 203). Groups began to address their social and environmental circumstances through environmental justice. [3] Eventually, the US government considered the issue through a benchmark report 'Environmental Equity: Reducing Risk for all Communities' (US Environmental Protection Agency, 1992; Bullard 1993).

The environmental justice movement contrasts with the ideas proposed by Summers [4] and with the 'standard view' of environmental management explained by Harvey (1996: 366-367, 373-376). The first view comes in the form of a memorandum to the World Bank encouraging polluters to migrate to lesserdeveloped countries, with lower costs for companies in clean-ups or legal challenges. Summers' logic also implied poor countries could benefit economically by accepting toxic industry, and that people with lower life expectancy could accept a higher toxic load, since they would die of other causes before health impacts of pollution materialised. This is a clear example of discrimination on the basis of economic and political power. The second view is that there should only be intervention in an environmental problem 'after the fact' so environmental concerns do not stand in the way of 'progress'.

Environmental justice continues to be an important socio-political movement in the USA (for example, Foreman 1998; Schlosberg 1999; Cole \& Foster 2001), but less so elsewhere. It is also starting to be addressed by researchers in other countries. Developments outside the USA have included context-specific interpretations of environmental justice and reflections on whether it is relevant when communities lack basic necessities. At a recent international conference, these differences were ventilated, hinting at legal, political, administrative, economic and social justice elements. [5]

Environmental justice has not become a focus of debate in Australia, despite its adoption of many US government environmental structures such as the Environment Protection Authority (EPA). This is in spite of a similar problem of industrial pollution. Why is this so? Is it due to an absence of implicit racism in the siting of industrial production (implicit racism in this context meaning minority groups bearing a disproportionate burden of pollution), a lack of grass-roots activism to raise awareness of the issues, or an unwillingness on the part of academia and/or government to acknowledge and research the problems if they should exist?

Here the debate is taken further with an Australian case study. We consider the way in which 'environmental justice' may be understood through the practical experience of a community in a specific geographic, social and political situation. In the Australian context, there is a great deal of emphasis on public participation in environmental policy and regulatory systems. This has been emphasised especially in the State of NSW, which is the setting for this study. In NSW, public participation is relevant to the operation and review of environmental legislation and in government decision-making. This is complemented by the 
constitutionally-prescribed system of governance in Australia, which includes the principle of accountability of government apparatus and freedom of speech concerning the way in which we are governed (Arcioni 2003). Public participation is therefore central to any concept of environmental justice Australian-style. It is this principle which is used to consider the notion of environmental justice in this case study.

The concept of public participation is shown here in the Australian context. However, it has also received some attention within recent environmental justice literature (see, for example, Zimmerman 1994; Lake 1996; Hunold \& Young 1998; Schlosberg 1999, 2003). These writers have criticised earlier literature for placing too great an emphasis on the distributive aspect of environmental justice and ignoring other understandings of 'justice'. The distributive element concerns how environmental risks are shared across a population, with the goal being an equitable distribution. The 'other' elements which are often ignored include procedural aspects of justice, arising from the ideal of a participatory democracy. These include public participation. Hunold and Young (1998: 89-90) have developed a list of requirements for participation. For the purposes of this study, the focus is on the ability of the public to have an authentic contribution to decision-making when the decisions affect their community.

\section{The Case Study in Context}

The case study is centred on the small industrial community of Port Kembla, NSW. Port Kembla is the principal industrial area of Wollongong, Australia's seventh largest city. It is approximately 80 kilometres south of Sydney, the nation's largest city and the NSW capital. The area has a long industrial heritage dating back to the 1850s with the opening of coal mines along the nearby coastal escarpment.

Port Kembla specifically has an industrial history dating back to 1908 , when the Electrolytic Refining and Smelting Company (ER\&S) commenced production. [6] It was a hazardous place for workers and residents alike. It produced a range of pollutants including sulphur dioxide and lead fumes and many workers experienced serious industrial accidents. Its success attracted three other companies - Metal Manufactures (MM) in 1915, Australian Fertilisers Limited (AFL) in 1921 and the Hoskins steelworks in the late 1920s. ER\&S, MM and AFL were all subsidiary companies of the Mount Morgan Gold Mining Company. [7]

By the late 1920s, the Port Kembla steelworks developed into the BHP steelworks, most recently renamed BlueScope Steel Ltd, which was listed on the Australian Stock Exchange on 15 July 2002. [8] Like the three Mount Morgan companies, the steelworks also brought employment, industrial pollution and environmental damage to the area. 
In the late 1980s and early 1990s, the smelter became engaged in a series of industrial disputes. These disputes became intractable and together with other problems facing the company, caused the copper smelter to close in 1995. Many thought that pollution from the plant was at an end. However, two Japanese businesses, Furukawa Co. Ltd and Nissho Iwai Co. Ltd, believed that the smelter was still commercially viable, especially with an extensive upgrade programme. They purchased a majority holding in the smelter. The Japanese companies then began the process of securing the necessary environmental and planning approvals for an upgrade. Residents opposed the recommissioning of the plant, especially given admissions by the new owners that the technologies would not eliminate air pollution and that they had applied for exemptions to emit unknown quantities of pollutants.

As detailed in the next section, Port Kembla was thereafter in a fight for environmental justice, though without naming it as such. Despite that fight, the smelter reopened in 2000, with a number of licence and operating conditions. From that date there were numerous pollution incidents which breached those conditions. These led to residents' complaints to the EPA (Hamilton 2002: 8789). Pressure mounted and prosecutions were commenced. Port Kembla Copper (PKC) pleaded guilty to six offences committed in 2000 and three offences in 2002. The NSW Land and Environment Court imposed fines for each offence (NSWLEC 2001a, 2001b, 2003).

On 15 July 2003, Craig Knowles (Knowles), the NSW Minister for Infrastructure, Planning and Natural Resources, announced that PKC had given undertakings to the NSW Land and Environment Court to comply with its development consent conditions. A media release from the minister's office, headed 'PKC Resolution', said in part:

Residents will be relieved to know that PKC has legally undertaken to implement significant technical and operational changes in order to achieve compliance with its conditions of consent.

This is a very good outcome for the community.

The undertakings on compliance particularly relate to brown spotting, water treatment, noise and environmental measures.

It is important for the community to be aware that in taking on this case, the government has taken positive steps to address the previous noncompliance (NSW Department of Land and Water Conservation 2003).

Thirteen days later, the board met in Tokyo, Japan and decided that the 'undertakings on compliance' were not in the company's financial interests. One estimate put the costs of compliance at \$AUS400m (Woolage 2003). Furukawa abandoned the undertakings it had given to a court and decided to close the 
plant. Residents who had fought for clean air and a copper smelter that lived up to the claims by company and government of environmental best practice saw their reasons for opposition vindicated. Meanwhile, the NSW government that had aggressively championed the opening of the works saw the demise of its attempt to maintain industry in an area with high unemployment.

With the plant facing imminent and permanent closure, the era of the copper smelter at Port Kembla seems to be nearing an end. But the phase of protest and decision-making in the 1990s remains a pertinent case study of community action and the implications of environmental justice in Australia.

\section{Citizen Action at Port Kembla}

Port Kembla is a multicultural community where the majority of residents come from non-English speaking backgrounds. It is one of many places that grew as a consequence of Australia's post-Second World War migration programme. Many residents work in the nearby steelworks and other industries, including the copper smelter, and have historically shown little resistance to the environmental excesses of polluting industries. However, the proposal to reopen the smelter in the 1990s divided the community. Many once-passive workers and residents became active protesters.

From when the smelter began operations in 1908, there was continuous pollution. For the first 40 years of the smelter's life, residents suffered mostly in silence at the smelter's emissions of sulphur dioxide and lead. Early public statements about the smelter in fact heralded the smoke and dust as evidence of prosperity and industrial advancement. By the 1940s, Port Kembla residents had had enough. Their private complaints and concerns about air pollution turned to public disquiet. Letters and deputations to the local council and progress association about levels of dust and acid fumes became a significant community issue in the late 1940s and early 1950s. [9] In 1950, the local state representative, Rex Connor, took the residents' concerns to the NSW Parliament (Hansard 1950: 435). The NSW Department of Public Health began measuring levels of fallout, turned part of the work of the Division of Industrial Hygiene over to air pollution control and in 1961 the NSW government introduced the Clean Air Act as part of its response to regulate or 'abate' air pollution. [10]

The Act did not eliminate the problems of air pollution at Port Kembla. While community pressure largely vanished after the passage of the legislation, Port Kembla residents remained concerned about the effects of industrial pollutants on their health. Public concerns prompted health and university authorities to carry out several studies, all of which pointed to high levels of lead pollution and other heavy metals (Beavington 1975: 67-71; Australian Academy of Science 1981; Bell 1981: 23-26; Gan 1982: 372-376). The studies showed the smelter emitted sulphur dioxide, lead and a host of other chemicals, at levels exceeding standards set by the National Health and Medical Research Council (NHMRC) 
and the World Health Organization. The pollution led to an estimated \$AUS7m (Hamilton 2002: 75) in compensation paid to residents because of damage to houses, pavements and cars; the company employing a loss assessor to deal with the quantity of claims.

As indicated in the previous section, the smelter was effectively closed in 1995, and put on a programme of 'care and maintenance' only, due to a combination of factors including industrial disputes and a repeated inability to comply with environmental controls imposed by the state government's EPA. In early 1996, residents discovered that Knowles, as Minister for Urban Affairs and Planning, [11] had consented to a reopening and upgrade proposal which included the injection of \$AUS $250 \mathrm{~m}$ into the smelter by the Japanese industrial consortium (Hansard 1997: 9461-9462).

Port Kembla residents protested against the decision. A Commission of Inquiry and an Environmental Impact Statement had followed the development application, but the community did not seem to be aware of the reopening, which was to occur in November 1996. According to some residents, only 12 households had been informed of the development application and not all of these could understand English very well (RATS to IAHS 1996). The 'salesmen' for the smelter, the Coalition for Economic Advancement (CEA), had given clear indications of the priorities in this development - jobs and investment. [12]

By comparison, the community focused on the health implications of the reopening and the lack of consultation. There was anecdotal evidence of a general feeling of environmental improvement in the period the smelter had been closed [13] as well as a strong perception about adverse effects on health caused by the industries. Between 1992 and 1995 a number of studies examined the levels of lead in the area around the smelter. The Illawarra Public Health Unit undertook a Roof Dust Study in 1992 (Chiaradia et al. 1997a; Chiaradia et al. 1997b), and in 1993 informed local residents surveyed not to disturb their roof dust without the use of adequate safety equipment. The Illawarra Environmental Health Unit and Illawarra Public Heath Unit conducted 'The Illawarra Child Blood Lead Survey', finding levels higher than NHMRC guidelines (Williams et al. 1995; Huo et al. 1999). This contrast in priorities between health and economic investment or 'progress' remained the most significant difference between the authorities and local residents.

The developers and government authorities called a public meeting in mid-1996, which established a government-run Port Kembla Residents Committee to appease the concerns of the locals and to represent them at the monthly Port Kembla Pollution Meetings. These in turn had been established in 1991 by the Independent mayor of Wollongong, Frank Arkell, due to the residents' concerns regarding pollution from the smelter (Hamilton 2002: 74). A committee member, David Gilmour, who remained actively opposed to the 
smelter, has described the Committee as 'paying purely lip-service' to residents' concerns (Gilmour 1997). Meetings lacked a formal structure and despite calls from residents there was no proper recording of meeting business. Residents called for a thorough health study to investigate the possible relationship between emissions from the smelter and the effects on the health of residents. No such study occurred.

In June 1996 residents established the protest group known as Residents Against the Smelter (RATS), which many believed would give the community's concerns a more effective voice. The people involved, all local citizens, lacked experience in environmental or political forums but felt strongly enough to forsake their previous loyalty to a major employer in the area and publicise the need for the protection of the locals' health. RATS' agenda was clear: to block the reopening of the smelter. In August 1996, it conducted a survey of the local area to ascertain support for, or opposition to, the smelter. It also convened several public meetings. RATS quickly gained widespread public support. This became clear from the number of residents who turned out for a street demonstration - in July 1996 more than 300 people marched past the smelter. The survey findings showed that $80 \%$ of the locals surveyed opposed the smelter's reopening. The group continued to attend meetings with the developers and local parliamentary representatives, but felt its concerns were falling on deaf ears. RATS sent letters to the Illawarra Area Health Service, Wollongong City Council (WCC) and local parliamentarians setting out its concerns.

At the end of 1996, RATS decided to change its name to Illawarra Residents Against Toxic Emissions (IRATE) and broaden its focus. In early 1997 it became an incorporated association largely to protect its members in the light of proposed legal action (IRATE 1997). RATS had been established to respond quickly to a specific community consultation programme which it considered inadequate. In contrast, IRATE was formed to become a more general voice for the community, to address the health issues raised at earlier community meetings and to be a focus for interacting with the developers and authorities. The group had gone through a learning process concerning the law surrounding developments and it believed there were deficiencies in the formal application for the reopening. This belief became the focus of the next stage of community action - legal action in the NSW Land and Environment Court challenging the legality of the government's consent for the smelter reopening and upgrade. IRATE believed the court was the appropriate place to challenge the development, and provide an opportunity to place on the public record information about the health problems experienced by Port Kembla residents.

IRATE initially planned to take the case in the group's name but due to delays in incorporation, one of its members, Helen Hamilton, decided to take action in her name. She withdrew from IRATE to avoid liability falling on the other members and applied for Legal Aid. Legal Aid is government support for legal action where parties satisfy a means and merit test. The NSW Legal Aid Commission granted 
Hamilton \$AUS18,000 and assigned Michael Sergent, a Wollongong-based Legal Aid solicitor, to the case. Tim Robertson, a Sydney barrister (now Senior Counsel), took on the case. Considering the tests applied to Legal Aid cases, it is reasonable to infer from the grant of aid that the community had some valid arguments and a reasonable chance of success. The case was filed on Christmas Eve 1996 and from that point onwards there were two parallel movements against the smelter - one, the ongoing work of IRATE in relation to information dispersal and health concerns, the other the preparation of Hamilton's legal arguments. The case was against three bodies: the Minister for the Department of Urban Affairs and Planning, and the two companies through which the copper smelter operated.

As the two movements progressed, the diverging agendas of health and community consultation and economic development became more distinct through the battles conducted in the local media. While IRATE and Helen Hamilton continued to gain support from the community and to network with other groups, [14] the developers - through the CEA, the local Federal Labor member Steven Martin, and the NSW Premier Bob Carr - derided the allocation of legal aid to Hamilton's challenge as 'an absolute joke'. Martin and the premier said that the top priority for Wollongong was new investment and job security and that Hamilton's legal challenge was nothing more than a frustrating delay for this development (Carr 1997; Failes 1997).

The preparation for the case continued. Unlike other parties to the dispute who had large legal teams and significant funds, unpaid volunteers helped prepare Hamilton's case. [15] She in turn kept the community informed of the reasons for, and developments in, the case through media releases and information distributed by IRATE. IRATE held public meetings, organised protests and conducted leaflet distributions to the local area. Funds were raised from donations and social events, while the office of Colin Hollis, a local Federal member of parliament, assisted with photocopying (Gilmour 1997). IRATE asked WCC to contribute funds. The council had given \$AUS20,000 to residents in Wollongong's northern suburbs to assist their opposition to the location of an international airport at nearby Holsworthy. It had also hosted community meetings in those suburbs. However, with IRATE's campaign, the council argued that it had given sufficient assistance through the establishment of the monthly Pollution Meetings, and declined to grant additional support. Many residents believed the council's response discriminated against those impacted by pollution in the Port Kembla area. Other examples of perceived discrimination included an absence of material in relevant community languages and the absence of community language interpreters at public meetings. [16] The group continued to receive considerable media coverage, with over four hours of airtime devoted to the smelter issue on news and current affairs programmes in the six months from the establishment of RATS to early 1997 (Rodwell 1997). 
On 29 May 1997, the Land and Environment Court began hearing the Hamilton case. When the parties arrived at the court, instead of opening addresses by the various legal representatives, the respondents applied for an adjournment. Thereason? The minister had introduced legislation into Parliament at 8.44 p.m. the previous evening and the respondents (the minister and the smelter companies) argued that the legislation would affect the utility of Hamilton's case. The effect of the legislation was to deem the consent to the smelter reopening valid, 'despite the existence of, or the decision in, any proceedings pending in any court immediately before the commencement of this Act' (Port Kembla Development (Special Provisions) Act 1997 (NSW): s. 7).

Debate on the legislation in Parliament made it very clear that any uncertainty or delay of the development was unacceptable and that the minister had taken it upon himself to determine that the challenge was merely 'technical' (Hansard 28 May 1997: 9461-9463). Clearly, the government drafted the bill with considerable haste and wanted it rushed through Parliament in order to stall the case. But if there was an urgent need to ensure the certainty and immediate commencement of the upgrading of the smelter, why did the government wait until just over 12 hours before the commencement of the case to introduce the legislation?

It could be argued that the allegations by Martin and the premier of a 'waste' of Legal Aid funds could have been avoided had the government validated the consent through such legislation some months earlier. Or was it, as IRATE and Robertson have speculated, that the government was acting because the information accumulated in preparation for the case, unknown to the government until close to the day of the hearing, revealed evidence of corroboration of the community's fears of adverse health risks (Gilmour 1997, Hamilton 1997, Rodwell 1997; Robertson 1997)? Whatever the answers, Hamilton's case was over before it had even commenced but after the expenditure of Legal Aid money and the time of Hamilton, her legal team and numerous volunteers.

\section{Observations on, and Implications for, Environmental Justice}

Can it be said that environmental justice is a useful concept with which to analyse environmental politics in Australia, or at least in this one specific context? Arguably, a number of factual elements evident from this case study were common in the community actions in the USA around which the term 'environmental justice' grew. The Port Kembla situation was one of working class residents, engaged in a fight for human health but against the backdrop of more stereotypically 'environmental' concerns, namely air pollution. The community engaged in the typical tactics of the US communities - protests, lobbying or communication with local elected representatives, fact-finding and self-education of the processes through which governmental decisions are made. What then can be said of this Australian example of a fight for environmental justice? The main points which can be perceived are the lack of voice in official decision- 
making (the consent process for the smelter reopening), the lack of representation by elected parliamentary members and the power imbalance between community activists, such as Hamilton, and the government, which wielded its power to override residents' legal action through legislation.

The case also highlights the contrast between public participation processes mandated by government and those avenues pursued by the community's own initiative. The government avenues, namely the Pollution Meetings and the opportunity to comment on development applications prior to approval, were perceived to be ineffective by the community in Port Kembla. The official representative channels via elected members of Parliament also seemed futile. Finally, the formal avenue of legal challenge was forestalled by government action.

The perceived lack of representation by elected parliamentary members dovetails with the dominance of party politics geared to economic advancement over the health of residents. This is shown by the position taken by Sullivan, the Labor Party member for Wollongong. He expressed concern for the health of his constituents and raised questions in parliament over the role of the CEA in the consent given to the reopening of the smelter. [17] However, when it came to the vote on the special provisions legislation, his words of support did not affect his actions - he voted for the party line.

Alternatives to the legislation may have been discussed by an Australian Labor Party caucus meeting. But citizens do not know whether this occurred because minutes of caucus meetings are barred from public release for 30 years. Regardless of whatever efforts were made to consider alternatives, the legislation went through NSW Parliament with considerable haste and with the support of every Labor member. Perhaps it is an example of what John Hatton, a former Independent parliamentarian, has suggested; 'if any of the Australian Parliaments democratically carry out these functions (making laws, safeguarding liberty, provisions of services), it is by accident not design. Democracy is an illusion' (Hamilton 1997).

This seems to be in contrast with the public participation avenues pursued by the concerned residents, taking the classic approach of protest, information dispersal and self-education. These avenues achieved publicity, earned governmental annoyance and eventually led to active and direct involvement in the legal process, in a questioning of the official position. However, even the access to that form of public participation was restricted, partly by costs inevitable in litigation, but eventually by the government itself foreclosing the debate through legislation.

The legislation was questionable in terms of its timing, and also for the way it diminishes the rights of the community to appeal a development consent. There are suggestions that it violates the distinction between the judiciary, the 
legislature and the executive in the structure of government in the state. The doctrine of separation of these powers is not as clearly entrenched at the state level as it is at the federal level in Australia, due to differences in the constitutions of the relevant jurisdictions. In fact, to date, the only element of the separation doctrine that the High Court of Australia has accepted as affecting NSW is that the judiciary must be independent of legislative and executive influence. [18] Nevertheless, there may be scope to argue that Knowles' involvement as Minister introducing the legislation as well as being a respondent in the Land and Environment Court proceedings did breach that limited aspect of the doctrine (Robertson 1997).

There is another avenue for attacking Knowles' actions. In Australia there is a policy that the federal government must act as a 'model litigant' in any court actions. Although these rules do not apply to the NSW government, there is clearly a 'standard of fair play to be observed by the Crown in dealing with subjects', including all tiers of government in Australia when a government or government officer acts as a party in litigation. [19] The introduction of the legislation, considering its timing and the actions of the government leading up to the eve of the case, was highly questionable in relation to whether it satisfied this standard.

This type of legislation is not unique in the history of the current state government. [20] Furthermore, the government did not only introduce the Port Kembla legislation the night before Hamilton's case was due to commence. It also introduced legislation which arguably would have had a more general negative effect on residents' ability to challenge developments. This legislation proposed changing the standard required to be followed by consent authorities in relation to parts of the planning process from one of 'strict compliance' to 'substantial compliance' (Hansard 1997: 9459-9460). The government argued this would allow an end to threats to 'jobs and the State's economy' by 'challenges which do not go to the substance or merits of an issue but seek only to delay by challenging technical points of the process' (Hansard 1997: 94599460). The effect of the bill was disputed. Non-government groups argued the changes were not to:

simply 'technical' points or red tape. They have an important purpose, namely, to ensure that people generally, and in particular those who are likely to be directly affected by a decision, are notified so that they have a chance to comment and participate in the decision . . . Breaches of these provisions cannot be 'cured' . . . If people have not been notified and have not been able to put their views forward, then any consent which has been issued cannot have taken those matters into account (NSW Young Lawyers 1998).

As with the Port Kembla legislation, the timing of this legislation is significant. Consider the comments by the Deputy Leader of the Opposition: 'It is extremely 
difficult to justify the speed with which this bill is being pushed through the House' (Hansard 1997: 9558) and those of the Independent member for Manly, 'It was introduced last night with no consultation . . . Where is the consultation with the community? Where is the consultation with environmental groups?' (Hansard1997: 9559). While researching the history of the legislation, the legal section of the relevant department refused to reveal the drafting dates of the legislation, as they were deemed to be 'too sensitive' (Scholtz 1997). This raises the obvious question: Why is knowledge of the dates when the Bill was drafted considered a sensitive matter? One clear implication is that communities lack even the most minimal political power needed to effectively participate in decision-making which affects their health and general environment.

This case study, involving a copper smelter at Port Kembla, affords an interesting snapshot of how a community, which had long borne the effects of industrial pollution, challenged a government's decision to reopen the smelter. Port Kembla residents had participated in many aspects of the smelter's history. Public participation from 1907 to the late 1980s took the form of communicating concerns to representatives on local councils.l

The residents accepted the decision of their representatives to build the smelter. Through their representatives on a larger council in the 1940s and 1950s, the residents participated in committee work and council decisions. The council did not always produce the outcomes that the opponents of the town's industrial pollution sought. However, Port Kembla residents accepted the decisions. Residents took their concerns to the NSW Parliament through petitions, meetings with, and deputations to, their local parliamentary representatives. Here too residents did not always see the outcomes they sought, but they accepted the outcomes and processes of the parliament. This history of begrudging acceptance continued until the government decided to accept an offer by a new owner of the copper smelter to reopen the plant. More precisely, it was not the decision to reopen the smelter that brought unprecedented community outrage, but the way the government went about ensuring that the smelter would reopen.

While the history of the smelter's discharge of industrial pollutants from 1907 to the late 1980s brought opposition and complaint, those responses were characterised by a public participation which followed clearly defined rules and procedures of expressing opposition and accepting and processing decisions from government. The history of this engagement with WCC, the NSW government and the various companies taught Port Kembla residents that by adhering to the rules established by these agencies, there was little room for change.

When residents followed these rules and sought change in line with the government's public participation guidelines, they quickly discovered that there was little, if any, opportunity for change. However, if residents went beyond these rules and investigated alternative methods, they found that the opportunities for 
change increased dramatically. This case study shows what happened in a small community with a history of industrial and political passiveness when it decided to revisit and reorder the notion of public participation to a process which gave them more options for change.

\section{Conclusion}

As a movement, environmental justice is a powerful way of achieving environmental equity in the USA. The environmental justice movement is more than another form of environmental protest and activism. It is a new paradigm of, and for, environmental protest. Robert Bullard describes it thus: 'It's more of a concept of trying to address power imbalances, lack of political enfranchisement, and to redirect resources so that we can create some healthy, liveable and sustainable types of models' (Bullard 1999). In the USA, the movement has had profound legal and political implications. It has identified and linked issues of racism, civil rights and the siting of toxic plants with fundamental questions about political and legal equity.

Environmental justice, both the concept and the movement, are yet to acquire prominence in Australia. However, the term 'environmental justice' need not be restricted to a small set of disputes in the USA in the 1970s. The issues of siting industries, negative health and environmental consequences of industry and public disquiet are issues relevant to people across time and space. When the notion of environmental justice 'arrives' here, it is possible that new legal and political consequences will flow from its application and understanding. This study, based on a dispute between government, industry and residents in the town of Port Kembla, brings out issues similar to those pervading the classic examples of 'environmental justice'. In this case, the residents were members of the community who did not normally take part in political disputes yet felt their interests and the interests of their environment were not being adequately protected by their elected government. This example shows that at least in this one Australian dispute, the US notion of environmental justice could be renamed in the Australian context as a fight for public participation. Such a notion seems at least to capture the physical efforts of the residents in attempting to be heard by their government. It also indicates their engagement with formal procedures and the problems which arise when government decisions in which residents seek to participate are being made by the same individuals who have the power to enact legislation which thwarts legal challenge.

For the residents of Port Kembla, their attempts to obtain environmental justice appear to have been sacrificed on the twin altars of political and economic expediency, although following a series of prosecutions, the smelter did close. The earlier process which saw the government and the company thwart the objectives of Port Kembla residents, Hamilton in particular, had a perverse irony. State parliament, hitherto seen as the seat of democracy and responsible government, had pushed through legislation with an indecent haste. Put another 
way, the very institution that many saw as protecting the interests of its citizens had turned on them.

\section{Notes}

1. See Hamilton (2002: 65-89) for Hamilton's account of her involvement.

2. See the bibliography available at MSU Extension, Environmental Justice Database. Available at: http://www.msue.msu.edu/msue/imp/modej/masterej.html (accessed 22 February 2005).

3. For example, First National People of Color Environmental Leadership Summit and the 17 Principles of Environmental Justice. Available at: http://gladstone.uoregon.edu/\%7Ecaer/17principles.html (accessed 29 October 2004).

4. Lawrence Summers was chief economist with the World Bank, whose memorandum referred to in the text is reproduced in Robbins, R (1999) Global Problems and the Culture of Capitalism (New York: Allyn \& Bacon) pp $233-236$.

5. The conference was titled 'Environmental Justice andMarket Mechanisms: Key Challenges for Environmental Law and Policy' and was held in New Zealand in 1998. See the papers published in New Zealand Journal of Environmental Law 2 (1998) and Richardson and Bosselmann (1999).

6. For a detailed account of the ER\&S's history at Port Kembla, see Mitchell (1982).

7. Ibid.

8. See 'About BlueScope Steel - Our History'. Available at: http://www.bluescopesteel.com (accessed 22 February 2005).

9. See, for example, 'Fumes at Port Kembla detrimental to health', Illawarra Mercury, 16 November 1945, p. 1.

10. See Smoke Abatement Committee (1958).

11. In 2003, the government restructured the bureaucracy. This department was merged into a super-ministry of Infrastructure, Planning and Natural Resources, with Knowles as minister.

12. Ian Wisken, Head of CEA, said they 'will go on any platform to identify new opportunities for jobs'. In 1991, CEA lobbied the NSW government to restrain the NSW EPA so 'development would not be brought to its knees' (Jopson 1997). 


\section{See Hamilton (1997: 3). See also RATS (1996).}

14. Local groups included the West Dapto community group fighting the proposal to dump slag and steel wastes in their area; the Students Representative Council at the University of Wollongong; the Northern Suburbs Social Justice community group; the Lead Reference Centre; the Total Environment Centre in Sydney; the Cancer Cluster Investigation Steering Committee; and parents from the Port Kembla Public School.

15. The three respondents each had a Queens Counsel and a junior barrister, as well as at least one instructing solicitor. See Land and Environment Court No 40307 of 1996, 29 May 1997.

16. Compare with the USA, where an application was inadequate because there were no community language translations of the relevant material pertaining to the proposed project. See Bullard (1993: 38).

17. Sullivan wrote to Rodwell 'You are probably aware that I am one of the few voices in Public Office in the Illawarra calling for the best results for the residents', October 1996. See also the following statements in Hansard: 'I suspect that the pressure [on the CEA] would be such as to cause the [CEA] not to be as honest as it otherwise would be in informing the local community and in its dealings with State government departments' (Hansard 1996: 3766).

18. See Kable $v$ The Director of Public Prosecutions for the State of New South Wales (1995) 189 CLR 51.

19. See Melbourne Steamship Co Ltd v Moorehead (1912) 15 CLR 333 at 342 per Griffith CJ; Scott v Handley [1997] FCA 404 at [44].

20. Other special provisions legislation includes Walsh Bay Development (Special Provisions) Act 1999 (NSW), announced by the government on the day the Court was to hear a challenge to that development; State Environmental Planning (Permissible Mining) Act 1996 (NSW), enacted between the hearing and delivery of judgment of an appeal from a successful challenge to the development and Kooragang Coal Terminal (Special Provisions) Act 1997 (NSW), which effectively confirmed the Minister's consent, avoiding the Court of Appeal decision. Hansard, NSW Parliamentary Debates; Legislative Council; 4 December 1997, p. 3096.

\section{References}

Arcioni, E. (2003) 'Politics, police and proportionality - an opportunity to explore the Lange test: Coleman v Power', Sydney Law Review 25(3): 379-90.

Australian Academy of Science (1981) Health and Environmental Lead in Australia (Canberra: Australian Academy of Science). 
Beavington, F. (1975) 'Some aspects of contamination of herbage with copper, zinc and iron', Environmental Pollution 8: 65-71.

Bell, A. (1981) 'Blood lead levels of some children in New South Wales', Medical Journal of Australia 1: 23-26.

Brown, P. (1995) 'Race, class and environmental health: a review and systematisation of the literature', Environmental Research 69: 15-30.

Bullard, R. D. (ed.) (1993) Confronting Environmental Racism: Voices from the Grassroots (Boston, MA: South End Press).

Bullard, R. D (1999) 'Environmental justice: an interview with Robert Bullard', Earth First! Journal, July. Available at: http://www.ejnet.org/ej/bullard.html (accessed 16 October 2004).

Carr, R (1997) 'An open letter from Bob Carr: port smelter all about jobs', Illawarra Mercury, 4 June, p. 2.

Chiaradia, M., Chenhall, B., Depers, A., Gulson, B. and Jones, B. (1997a) 'Identification of historical lead sources in roof dusts and recent lake sediments from an industrialised area: indications for lead isotopes', The Science of the Total Environment 205: 107-28.

Chiaradia, M., Gulson, B., James, M., Jameson, C. and Johnson, D. (1997b) 'Identification of secondary lead sources in the air of an urban environment', Atmospheric Environment 31: 3511-21.

Cole, L. and Foster, S. (2001) From the Ground Up: Environmental Racism and the rise of Environmental Justice movement (New York: New York University Press).

Failes, G. (1997) 'Wake up Wollongong: Carr lashes opponents of Port Kembla smelter', Illawarra Mercury, 13 February, p. 1.

Foreman Jr., C. (1998) The Promise and Peril of Environmental Justice (Washington, DC: Brookings Institute Press).

Gan, I., Shlier, G. and Innes, C. (1982) 'Blood lead levels in school children in the Port Kembla area', Medical Journal of Australia 2(8): 372-76.

Hamilton, H. (1997) Presentation to 'Who Cares About the Environment?' Conference of the Australian Institute of Environmental Health and the Australian Institute of Building Surveyors, NSW, August.

Hamilton, H. (2002) 'Port Kembla and the Fight Against the State', in K. McPhillips (ed.) Local Heroes: Australian crusades from the environmental frontline (Annandale: Pluto Press), pp. 65-89.

Hansard, NSW Parliamentary Debates; Legislative Assembly: 28 September 1950 (2nd series) Vol.194, p. 435; 27 June 1996, p. 3766; 29 May 1997, p. 9559; 28 May 1997, pp. 9461-63; 28 May 1997, pp. 9459-60; 29 May 1997, p. 9558; Legislative Council: 4 December 1997, p. 3096.

Harvey, D. (1996) Justice, Nature and the Geography of Difference (Cambridge: Blackwell Publishers).

Hunold, C. and Young, I. (1998) 'Justice, democracy, and hazardous siting', Political Studies XLVI: 82-95.

Huo, X., Crisp, P. and Cohen, D. (1999) 'Source apportionment of fine particles in the Wollongong-Port Kembla area during 1992 \& 1993', Clean Air 33(1): 26-35. 
Interview: David Gilmour, Chairperson of IRATE, 10 September 1997; interview with Glenn Mitchell.

Interview: Helen Hamilton, 10 September 1997; interview with Glenn Mitchell.

Interview: John Scholtz, Legal Section, NSW Department of Urban Affairs and Planning, 18 September 1997; interview with Glenn Mitchell.

Interview: Olive Rodwell, Vice-Chairperson of IRATE, 11 September 1997; interview with Glenn Mitchell.

IRATE (Illawarra Residents Against Toxic Emissions) (1997) IRATE, Minutes, January.

Jopson, D. (1997) 'Battle of the big smoke', Sydney Morning Herald, 11 March, p. 11.

Kyte, J. (1994) 'Environmental justice: the need for equal enforcement and sound science', Journal of Contemporary Health Law and Policy 11(1): 253-80.

Lake, R. (1996) 'Volunteers, NIMBYs and environmental justice: dilemmas of democratic practice', Antipode 28(2): 175-92.

Melosi, M. (1995) 'Equity, eco-racism and environmental history', Environmental History Review 19(3): 1-16.

Mitchell, G. (1982) 'Company, community and governmental attitudes, and their consequences, to pollution at Port Kembla, with special reference to the Electrolytic Refining and Smelting Company, 1900-1970', unpublished doctoral thesis, University of Wollongong.

NSW Department of Land and Water Conservation (2003) 'Port Kembla Copper Resolution'. Media Release - Minister's Office, Sydney, 15 July.

NSW Young Lawyers (1998) NSW Young Lawyers to the Honourable Elisabeth Kirkby (extract of letter), published in Hansard (Parliamentary debates), NSW Legislative Council, The Hon Elisabeth Kirkby, 9 September, p. 11192.

Port Kembla Development (Special Provisions) Act 1997 (NSW), s. 7.

RATS (1996) letter from RATS (Residents Against the Smelter) to Illawarra Area Health Service, 20 October.

Richardson, B. and Bosselmann, K. (eds.) (1999) Environmental Justice and Market Mechanisms: Key Challenges for Environmental Law and Policy (London: Kluwer Law).

Robbins, R. (1999) Global Problems and the Culture of Capitalism (New York: Allyn \& Bacon).

Robertson, T. (1997) submissions to the NSW Land and Environment Court, 29 May.

Schlosberg, D. (1999) Environmental Justice and the New Pluralism: The Challenge of Difference for Environmentalism (Oxford: Oxford University Press).

Schlosberg, D. (2003) 'The justice of environmental justice: reconciling equity, recognition, and participation in a political movement', in A. Light and A. deShalit (eds.) Moral and Political Reasoning in Environmental Practice (Cambridge, MA: MIT Press), pp. 77-106.

Smoke Abatement Committee (1958) Report on Air Pollution in New South Wales (Sydney: Smoke Abatement Committee). 
US Environmental Protection Agency (1992) Environmental Equity: Reducing Risk for all Communities, Environmental Protection Agency, Washington, June.

Williams, C., Calvert, G., Gan, I., Kacprzak, J., Kreis, I., Westley-Wise, V. and Willison, R. (1995) Evaluation of Possible Environmental Sources of Lead Affecting Children in Port Kembla, Kemblawarra, Warrawong and Cringila (Wollongong: Illawarra Public Health Unit).

Woolage, D. (2003) 'Markets, environment spell the end for PKC', Illawarra Mercury, 2 August.

NSWLEC (2001a) Environment Protection Authority v Port Kembla Copper Pty Ltd [2001]

NSWLEC 174 (2 August).

NSWLEC (2001b) Environment Protection Authority v Port Kembla Copper Pty Ltd [2001]

NSWLEC 223 (28 September).

NSWLEC (2003) Environment Protection Authority v Port Kembla Copper Pty Ltd [2003] NSWLEC 256 (31 October).

Zimmerman, R (1994) 'Issues of classification in environmental equity: how we manage is how we measure', Fordham Urban Law Journal 21: 633-69. 